\title{
Teaching with an Attitude: Finding Ways to the Conundrum of a Postmodern Curriculum
}

\author{
Ana Paula Martinez Duboc \\ Faculty of Education, University of São Paulo, São Paulo, Brazil \\ Email: anaduboc@usp.br
}

Received October $30^{\text {th }}$, 2013; revised November 30 ${ }^{\text {th }}$, 2013; accepted December $7^{\text {th }}, 2013$

\begin{abstract}
Copyright (C) 2013 Ana Paula Martinez Duboc. This is an open access article distributed under the Creative Commons Attribution License, which permits unrestricted use, distribution, and reproduction in any medium, provided the original work is properly cited. In accordance of the Creative Commons Attribution License all Copyrights (C) 2013 are reserved for SCIRP and the owner of the intellectual property Ana Paula Martinez Duboc. All Copyright (C) 2013 are guarded by law and by SCIRP as a guardian.
\end{abstract}

Several scholars in the field of education have questioned the constituent aspects of a curriculum that would better respond to the rising demands in contemporary societies. The relevance of such enquiry finds its place in the very transformations in today's societies marked by significant changes in the ways of knowing, being, and acting primarily due to the advent of new digital media in more recent globalizing processes. As Burke (2009) has stated, if schools wish to maintain their relevance in society, they must take into account such changes by first and foremost acknowledging the new and complex ways of making meanings in out-of-school literacy practices as equally legitimating those happening within school contexts. Along with Burke (ibid.), this paper advocates the need of rethinking the notion of curriculum in the light of the new ontologies and epistemologies of postmodernity. Such task proves itself to be a conundrum inasmuch as the very notion of curriculum has been traditionally founded on modern principles such as linearity, stability, and universality (Silva, 2009). In view of this, how can educators respond to the challenge of redefining what should be taught in schools in postmodern times so that students would better perform in relation to the self and the other within their social practices? This paper aims to analyse the relationship between postmodern philosophical concepts, curriculum theory and educational practice by presenting the notion of curricular attitude (Duboc, 2012) as a local redesign of teaching practices within a Brazilian educational context. Despite being situated in the field of foreign language teaching, the notion of a curricular attitude might be of interest of other areas of knowledge since it seeks to revisit teaching practices in the light of wider philosophical concerns.

Keywords: Postmodernity; Curriculum Studies; Curricular Attitude; Language Teaching; Teacher Education

\section{Introduction}

History (...) shows that change produces anxiety, particularly if it involves a move from a comfortable climate of familiarity to an unpredictable arena of uncertainty. But, such a change can be less disorienting if it develops within a context in which the participants themselves play a role in making decisions and in implementing those decisions (Kumaravadivelu, 2006: p. 225).

Several scholars in the field of education have questioned the constituent aspects of a curriculum that would better respond to the rising demands in contemporary societies. The relevance of such enquiry finds its place in the very transformations in today's societies marked by significant changes in the ways of knowing, being, and acting primarily due to the advent of new digital media in more recent globalizing processes.

In a broad sense, these new ways of knowing, being, and acting reflect the new epistemological basis within post-typographical societies. With respect to ways of knowing, people are now constructing new knowledge under the logic of distribution, collaboration, sharing, and experimenting (Lankshear \&
Knobel, 2006) to the detriment of concentration and normatization as predominant elements in typographical societies. When it comes to the new ways of being and acting, these generally refer to a greater deal of participation in different social practices through a vast option of media devices by which postmodern individuals perform, interact, and engage with each other.

Such scenario in constant and rapid change does bring anxiety to those who might have been accustomed to traditional ways of knowing, being, and acting. Nonetheless, taking the premise that an educator is responsible of their learners' becoming to this world (Biesta, 2006), we must question the implications of these social transformations to education in an attempt to bring forth answers on what is to be taught at contemporary schools in different parts of the world so that learners are better prepared to respond to these new social demands. As Burke (2009) has stated, if schools wish to maintain their relevance in society, they must take into account such changes by first and foremost acknowledging the new and complex ways of making meanings in out-of-school literacy practices as equally legitimating those happening within school contexts. 
Along with Burke (ibid.), this paper advocates the need of rethinking the notion of curriculum in the light of the new ontologies and epistemologies of postmodernity. Such task proves itself to be a conundrum inasmuch as the very notion of curriculum has been traditionally founded on modern principles such as linearity, stability, and universality (Silva, 2009). In view of this, how can educators respond to the challenge of redefining what should be taught in schools in postmodern times so that students would better perform in relation to the self and the other within their social practices? This paper aims to analyse the relationship between some postmodern philosophical concepts, curriculum theory and educational practice by presenting the notion of curricular attitude (Duboc, 2012) as a local redesign of teaching practices within a Brazilian educational context. Despite being situated in the field of foreign language teaching, the notion of a curricular attitude might be of interest of other areas of knowledge since it seeks to revisit teaching practices in the light of wider philosophical concerns.

\section{The Postmodern Curriculum: Why a Conundrum}

As Lyotard (2004) states, postmodernity refers to the cultural state subsequent to major changes in the field of Science, Literature, and the Arts which had been primarily founded on Newtonian and Cartesian principles until the late $20^{\text {th }}$ century. Such changes helped define what came to be known as postindustrial societies and the following emergence of new ways of knowing, being, and acting that would question the modern grand narrative, moving towards a process of legitimizing heterogeneous and localized knowledge through a new logic of uncertainty and instability.

Along with Lyotard (ibid.), Silva (2010) defines postmodernity as both an aesthetic and epistemological change in relation to modernity due to its critique towards notions such as purity, abstraction, and totality. Contrary to these categories, postmodern discourse would then embrace diversity, situatedness, and contingency (Giroux, 1993) shedding new light to the understanding of social practices as these are assumed to be inherently characterized by discontinuities and contradictions (Torres, 2003).

Under such premises, Hall (2004) claims for the need of addressing issues such as identity, nation, and culture through the complexity and fluidity of new social relationships. In this respect, the hitherto centered and sovereign subject whose social roles would be easily spotted has now been replaced by a decentered and fragmented subject and the subsequent difficulties when attempting to define their social and cultural role not to mention their own identity in relation to themselves (Hall, 2004: p. 9).

Regardless of the several definitions ${ }^{1}$ one might find when it comes to the understanding of these more recent times, this paper views postmodernity as more related to dialogue than to rupture. In this respect, it seems that contrary to the strong sense of rupture between positivist scholars and precedent metaphysical theories-Comte (1978: p. 102) himself would accuse all precedent metaphysicians of being inconsequent speculators-postmodern discourse seems to favour a dialogi-

\footnotetext{
${ }^{1}$ One might also find terms such as "liquid modernity" (BAUMAN, 2001) and "late modernity" (GIDDENS, 2002), as alternative understandings of what this paper has been calling "postmodernity” along with Lyotard (2004) Hall (2004) and others.
}

cal approach which views modernity as the basis of a better understanding of our times (Cordeiro, 2002) through a genealogy and perspective-based approach (Foucault, 2009; Britzman, 1991).

In view of these brief considerations on some of the constituent aspects of postmodernity, this paper agrees with Silva's statement (2010) on the somehow "impossibility" of referring to a postmodern curriculum. The author (ibid.) claims that the notion of curriculum is the very materialization of modern elements inasmuch as for long centuries it has been conceived of under the logic of linearity, stability, and universality.

By assuming a genealogical look upon the history of curriculum within formal educational contexts, one might identify such linearity, stability, and universality from Ancient times until the Modern paradigm. As Silva (2010) explains, from Ancient Greece until the Renaissance, education set its base on both so-called trivium and quadrivium: the former would comprise the teaching of Grammar, Logic, and Rethoric whereas the latter would comprise the teaching of Astronomy, Geometry, Arithmetic and Music. In both curricular programs, the purpose of education would be related to a gradual transmission of stable contents (i.e. the canon in the field of Literature) which would be passively received and reproduced by learners in a process where curiosity, questioning and reinterpretation were absent. A few centuries later, in the Age of Enlightenment, the curricular program gains a more rational and specialized approach, leading to a hyper-disciplinarization through the creation of new disciplines (Doll Jr, 1997; Macedo, 2007; Morin, 2005).

As Doll Jr (1997) states, the modern curriculum puts suppositions, beliefs, and paradoxes aside in an attempt to focus on "self-evident" contents which then would be acquired by the learner through what Kumaravadivelu (2006) calls "the criteria of complexity", that is to say, contents would be displayed from simple to complex as well as from an arbitrary "beginning" to an arbitrary "ending”, resonating the positivist principles of selection and gradation.

According to Monte Mór (2008, 2010), particularly in the field of foreign language teaching, such two principles are still very recurring in many classrooms in which teachers, for instance, usually follow a "pre-determined" sequence of grammar structure teaching, being the Verb To Be the first, followed by the Present Progressive Tense, then the Simple Present Tense, and so forth. As for the universal aspect in foreign language curricula, this might be seen whenever one still finds a striking predominance of hegemonic cultural and linguistic varieties in many of the language textbooks available in the market, whose narratives are taught-and here I quote Adichie (2009) ${ }^{2}$-as if they were "a single story". Despite all recent developments in language policies and curriculum studies worldwide, particularly those contributions signalled by critical applied linguistics as well as post-colonial and post-structuralist studies, unfortunately a careful analysis on textbook industry still reveals such high emphasis on linearity, stability, and universality.

If on the one hand, many of us find ourselves in a postmodern era marked by uncertainty and instability which embraces social, cultural, linguistic, ethnic diversity, on the other hand, many of us might still witness curricular programs pretty much based on a linear, stable, and universal way of organizing con-

\footnotetext{
${ }^{2}$ ADICHIE, C. The danger of a single story. TED Global talks, Jul 2009. (last checked 28 October 2013)
}

<http://www.youtube.com/watch?v=D9Ihs241zeg > 
tents regardless of our area of knowledge. Whether such uncertainties and instabilities of recent times are either positive or negative, it seems to be common ground that important social changes are happening in different parts of the world. Along with Burke (2009), to whom schools must acknowledge such changes and learn from them, this paper advocates for the imperative need of rethinking the very notion of curriculum towards these new social demands. This would imply looking at the traditional curriculum under the perspective of a different ontological and epistemological basis brought up in contemporary societies as discussed in the subsequent section.

\section{Finding Ways to the Conundrum of a Postmodern Curriculum}

In an attempt to respond to the challenge of coming up with a postmodern curriculum, several scholars (Biesta, 2006, 2010; Britzman, 1991; Doll. Jr., 1997; Kress, 2000; 2008 to name a few), have contributed with very insightful ideas which then might be interpreted according to the specificities of each area of knowledge.

By rediscussing the praxis in teacher education programs, Britzman (1991), for instance, advocates for a dialogical restructuring of curricular programs which would acknowledge the existence of multiple realities, voices and discourses in ongoing tension within the educational context. Such complex and contradictory scenario would then serve as the starting point of a new notion of curriculum by assuming perspectivism as key element to the detriment of a high emphasis on self-evident bits and pieces of knowledge. As the author states (Britzman, 1991: p. 2):

Enacted in every pedagogy are the tensions between knowing and being, thought and action, theory and practice, knowledge and experience, the technical and the existential, the objective and the subjective. Traditionally expressed in dichotomies, these relationships are not nearly so neat or binary. Rather, such relationships are between expressed as dialogic in that they are shaped as they shape each other in the process of coming to know.

By analysing postmodern art and architecture, Doll Jr (1997), in turn, pinpoints three useful characteristics to his draft of a postmodern curriculum, that is to say, the necessary dialogue with tradition (in place of an abrupt rupture); the eclectic and pluralist nature of postmodernity (in place of the hitherto monolithic nature of the modern paradigm); the plays of meanings and interpretations (in place of the previous deification of concepts and practices). In sum, the notion of a postmodern curriculum, in Doll Jr.'s terms, would be based on an experiential, generative, and hermeneutic approach to the detriment of the traditional curriculum based on transmission, verification, and representation of truths. This somehow resonates Foucault's concept of curriculum as a regime of discourse, as recalled by Britzman (1991), inasmuch as it "intones particular orientations, values, and interests, constructing images or cultural myths” (Britzman, 1991: p. 17).

Scholars such as Kress (2000, 2008) have discussed curricular issues in the light of the new multimodal meaning making processes that have emerged with the advent of new digital media. Among several aspects, Kress (2008) claims that a curriculum for instability would necessarily refer back to ethics inviting us to question, among other aspects, who adds value to a certain object and how such values affect oneself, the people around one's community as well as the people from different social groups. When Kress (ibid.) brings these questions at stake, he actually leads us to question the arbitrary nature of curriculum and the subsequent need for us, as ethical teachers, to "denaturalize" what seems to be natural (Menezes de Souza, 2006, 2011) by bringing to class different perspectives.

Similar attention to the importance of ethics in contemporary societies is brought by Biesta (2006). By relating the notions of responsibility, plurality, action and ethics, the author revisits the idea of learning by conceptualizing it as a response, to the detriment of the traditional view of learning as acquisition. In practical terms, this implies a notion of curriculum that would invite learners to ethically respond to their surrounding concepts, practices, and traditions. In order to do so, Biesta (ibid., p. 91) advises us that such process is not always pleasant, being much closer to a pedagogy that disturbs, deconstructs, interrupts stable and universal contents previously learned:

A pedagogy of interruption is, therefore, a pedagogy that aims to keep the possibility of interruption of the "normal" order open. It is first of all a pedagogy committed to the possibility of interruption and perhaps also a pedagogy that itself will interrupt. (...) A pedagogy of interruption is not a "strong" pedagogy; it is not a pedagogy that can in any sense guarantee its "outcomes"

Bearing in mind the contributions of these authors, the table below (Table 1) is an attempt to display the key concepts when one tries to identify some of the categories that would be welcomed in a supposed postmodern curriculum (Duboc, 2012).

Modern education would view learning as acquisition of clear-cut, objective, and universal contents which were to be transmitted by the teacher. In a broader sense, such model relies on the notion of an external, monolithic reality which would then be simply attested or "verified" by the subject. In the language classroom, this might be evident whenever the students are asked to decode text meanings by simply "verifying" them as if they were out there, displayed among words. Postmodern education, in contrast, would view learning as knowledge construction, which allows us to think of learning as a response (Biesta, ibid.) for its subjective nature and the imminent need for action in social life. Similarly, in such paradigm, reality is also a construction, a perspective, so to speak. When one teaches under this logic, students are invited to interpret text meanings to the detriment of mere verification.

As one can see, the categories on the right might be typically associated with the realm of subjectivity, which then gives room to the frowned upon argument of "anything goes" in postmodern studies (particularly post-structuralist ones). Nonetheless, this paper advocates the possibility of bringing forth teaching practices that would be based on the notions such as response, perspective, and interpretation as new elements in a so-called postmodern education. In other words, if we assume such elements as important ones to be brought in our teaching practices, we might come up with practical actions within our educational contexts. Such teaching practices refer to what I call a curricular attitude (Duboc, 2012) which could either

Table 1.

Key concepts in two distinct ideas of a curriculum.

\begin{tabular}{ccc}
\hline & The modern curriculum & A postmodern curriculum \\
\hline \multirow{3}{*}{ Key concepts } & acquisition & response \\
& representation & perspective \\
& verification & interpretation \\
\hline
\end{tabular}


emerge between the cracks ${ }^{3}$ within the classrooms or previously be planned by teachers in accordance with a set of conceptual and methodological choices as discussed in the following section.

\section{On the Notion of Curricular Attitude: Conceptual and Methodological Issues}

The notion of curricular attitude (Duboc, 2012) resulted from a $\mathrm{PhD}$ research which sought to bring forth new teaching practices in the light of some postmodern concepts. The research involved the planning and implementation of activities within undergraduate students from a Language Teacher Education program in the city of Sao Paulo, Brazil. By that time, such attitude would occur in relation to any of the curricular components, that is to say, the course plan, the textbook, and, mainly, the discursive practices among the teacher and her students which often revealed their personal concepts, beliefs, and experiences towards different emerging topics. Before describing one of these experiences as an illustrative example, it might be important to clarify its underlying conceptual and methodological aspects.

In order to better understand the use of the term attitude in the present paper, it is important to mention that one of the main premises of such investigation referred to the need of a critical perspective in the teaching of a foreign language. Several studies have stated the new roles of foreign languages in global digital times and the emerging need of providing our students with new abilities and strategies which are now paramount for their active participation in these new complex literacy practices. In other words, in a global world where different kinds of discourse rapidly circulate among interconnected people, schools/colleges must prepare students to both critically read and position themselves towards the (multi)literacy practices they engage with.

How does one teach the other to be a critical agent? As Morgan (2010, p. 35), explains, there is a strong connection between agency and identity for the process of learning "involves a process of identification". To put it differently, one will be critically acting if one assumes critique as part of their identity. Such "learning to be a critical agent"—which might imply learning/accessing new roles of identity—would not take place in a clear-cut, stable, and universal process as we might infer from Morgan (2010: p. 44):

Acquiring a new role of identity may involve different forms and pathways of learning. (...) We can't develop a transformative or libratory agency in the same way we might promote grammatical or methodological competence in LTE.

Another important thing to bear in mind when teachers attempt to foster agency among students is the impending danger of indoctrination. How does one know the boundary between one's intention to foster other's agency and their wish to become transformative agents?

Back in the seventies, mainly founded on the ideas of Paulo Freire, critical pedagogy would aim to empower students in view of their oppressed living and working conditions. Under such pedagogy, educators would teach students to read both the world and the word critically as pre-condition for an inclusive and just society. In more recent times, that notion of critique has been revisited in a way that it now assumes less a revolu-

${ }^{3}$ The term "between the cracks" might be read as "between the gaps" interchangeably. tionary tone and more a problematizing attitude (Pennycook, 2001). In other words, the very notion of critique has been reconsidered in postmodern times so that its previous empowering and indoctrinating stance now seems to give room to a more collaborative understanding of what it means to develop a critical approach in the classroom.

The impasse of such imminent indoctrinating approach by which a teacher would teach students how to be critical agents has been revisited by the concept of critical literacy. According to Muspratt et al. (1997), critical literacy is a pedagogical orientation that views literacy as a social practice and the subsequent need of a deconstructive work towards the cultural meanings of texts. As Shor (1999) states, this fosters the understanding of our own social and historical construction enabling us to transform any aspect of our lives if we wish so. Originally stemmed from Critical Theory, Sociology, and Anthropology, among other disciplines, critical literacy scholars (Comber, 2001; Green, 1997; Wooldridge, 2001 to name a few) have defined such orientation as a philosophical posture, an attitude so to speak, in place of the notion of a pre-determined method:

Critical literacy is an orientation to literacy: it is not something separate from literacy in general, or a particular part of literacy (...) Critical literacy is not a technique or set of strategies, but rather, part of a pedagogy underpinning a whole approach or classroom practice. A critical approach to literacy is about decoding and encoding the social, political, and ideological situatedness of literacy (Wooldridge, 2001: p. 259)

By taking the premise that agency is an essential ability in today's societies and by assuming a notion of critique that is closely related to a problematizing attitude rather than an indoctrinating method, I come up with the notion of a curricular attitude in response to what I consider, along with Silva (2010), a conundrum when one attempts to neatly define a postmodern curriculum. To put it differently, on the apparent impossibility of designing a postmodern curricular program, the idea of a postmodern curriculum would rely on our critical attitude towards pre-existent curricula. By recalling the table previously displayed in this paper, a response, perspective, and interpretation-based approach would not be located within pre-determined curricular contents with top-down pre-established techniques; on the contrary, such approach would emerge in the spaces between subjects and objects - that is to say, on the way teacher and learners relate themselves to any of the texts available out there in the classroom.

Taking into consideration Biesta's above words and his notion of interruption as an important aspect in today's curriculum, it might be fruitful to think of our attitudes towards our curricular programs as the very basis of a new understanding of curriculum in postmodern times: the way we look at its components and how we address such components might make a difference in the process of our students' becoming. In other words, the extent of their critical agency might be directly related to our attitudes as educators.

It might be worth mentioning that the term attitude per se has appeared on several philosophical studies, such as an essay written by Foucault (1984) in which the post-structuralist scholar relates both concepts of critique and attitude:

The critical ontology of ourselves has to be considered not, certainly, as a theory, a doctrine, nor even as a permanent body of knowledge that is accumulating; it has to be conceived as an attitude, an ethos, a philosophical life in which the critique of what we are is at one and the same time the historical 
analysis of the limits that are imposed on us and an experiment with the possibility of going beyond them.

As for a closer relation between a critical way of teachingwhich presupposes a deconstructive exercise-and the concept of attitude, Green (1997: p. 231) states that:

Deconstruction is to be reckoned as reading, as a specific mode of reading practice. As such, it encompasses both a politics and an ethics, understood not so much in terms of "method" or a "program" as of a distinctive, and distinctively wordly, attitude. That is to say, deconstruction is to be grasped as a strategy, an attitude, a stance toward texts, institutions, the social world and Being itself.

Along with several scholars from the field of language teaching (Brown, 1994; Graves, 1996; Richards, 1989), this paper acknowledges the importance of course planning and lesson planning. In this respect, one might ask: How can we come up with curricular planning in relation to this notion of attitude? In other words, will there be a way of planning such attitude towards the curriculum? The answer would be yes, since, as previously stated, such attitude could either emerge between the cracks within the classroom context or previously be planned by teachers in accordance with certain methodological choices.

By the term "between the cracks" within the classroom context, I mean those moments in which we, as teachers, immediately identify fruitful spaces for expanding perspectives (Monte Mór, ibid.). Such expansion might occur by comparing and contrasting viewpoints, discussing further aspects on a specific theme, relating global and local contexts critically, inviting students to position themselves towards what they think and what others think about a certain issue, and so forth. Such fruitful moments in the classroom - the cracks in the curriculum, I would say, or, in Morgan's terms, the small spaces and places (Morgan, 2010) — are not necessarily planned for they might emerge by a student's comment on a topic, a recent event broadcast by the local news, or even the way we interpret a certain image displayed on a textbook. The way I see it, our attitude between these cracks might have a greater social effect inasmuch as, by the very moment we disturb our students' assumptions, we might be contributing to a better acceptance of difference. It is worth noting, however, the necessary teacher preparation whenever opening up spaces for difference since there is no control on what students might bring out to the classroom.

Likewise, I also find it possible to preplan a set of activities with the intent of interruption. In such case, a careful critical analysis of any curricular components might lead us into a previous recognition of those cracks to be expanded. By assuming a sociological look on the curriculum as a social and ideological product, by curricular components I mean anyone and anything inscribed within an educational context: the teacher, the students, the textbook, the classroom architecture, the social etiquette, what students (don't/can't) say, what students (don't/ can't) do-these are all aspects that help produce the very notion of curriculum. I believe whenever we see those cracks in advance as emerging possibilities for critical expansions, it is our role, as active educators, find room for such expansion within our curriculum.

The following figure (Figure 1) is an attempt to visually display the notion of curricular attitude as presented in this work. By trying to summarize which contents, procedures, resources, and purposes would coherently respond to the theoretical

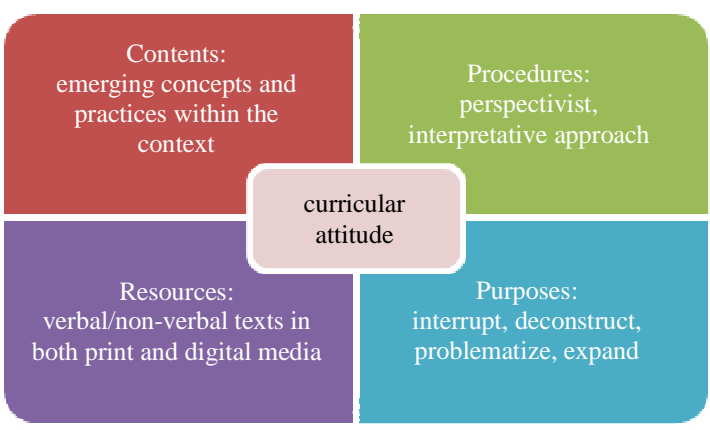

Figure 1.

Curricular attitude and its components: a visual representation.

framework of this paper, I find myself in an uncomfortable situation since tables and figures might convey a stabilizing and universalizing purpose. Nonetheless, the way it has been summarized relies on a locally designed course plan for its own commitment to local needs, interests, and expectations. An example of a local redesign is shared in the subsequent section.

\section{Curricular Attitude: A Research Experience in Brazil}

The local curricular redesign, that is to say, my on attitude towards a pre-existent curriculum so that I would provide students with possibilities for interruption and worldview expansion is actually a reinterpretation on some of the categories presented by Kalantzis and Cope (2008) as well as Monte Mór (2008, 2011) as follows ${ }^{4}$ :

- Experiencing the known

- Experiencing the new

- Conceptualizing/Categorizing

- Finding local and global connections

- Expanding worldviews

- Transforming

Out of several cycles of action implemented through a oneyear collaborative-action research on a Teacher education program, I share one of the set of activities which was thought after a female student's comment on the issue of gender roles. At that specific day, the teacher was actually discussing about sports as part of one of the textbook topics. By that time, students were expressing their opinions on the topic. The striking comment presents as follows:

Rebeca: I like soccer. I go to stadiums once in a while

Camila: Ahah! Of course... You look like a man!

(...)

Voilà! Here is a fruitful crack within this curriculum, which gives room to the teacher's attitude in search of disturbing students to think differently. Although simple at first glance, the student's comment raises the complex issue of gender ${ }^{5}$ since Camila's comment - which reveals her surprise towards the fact her female classmate often goes to soccer stadiumsseemed to imbue a stereotypical view of gender roles, which then might lead to prejudicial behavior. According to Bourdieu (1996), such essentialist way of perceiving the world makes human beings distinct from one thing/person/event to another.

${ }^{4} \mathrm{~A}$ more detailed explanation of each of these categories is found on Duboc (2012), available on http://www.teses.usp.br/teses/disponiveis/8/8147/tde07122012-102615/pt-br.php (last checked 28 October 2013).

${ }^{5}$ On 14 May 2013, The Justice's National Council of Brazil issued a ruling requiring all civil registers of the country to perform same-sex marriages. 
Despite sounding "natural” to many people, such distinctions are actually socially produced. One of the goals of critical education is to deconstruct/denaturalize such classificatory scheme. If one bears this goal in mind, such class must be "interrupted" in Biesta's terms.

Besides that, it is worth mentioning that the textbook per se provides us with other insightful ideas for it represents certain sports being played by either man or woman, not to mention the subsequent lesson which, under the heading "family", would bring the photo of a traditional nuclear family ${ }^{6}$. Considering myself as responsible for how the other responds to the world (Biesta, ibid.), I could not leave it behind and decided to plan the following sequence of activities (as shown in Table 2) based on the above categories.

The whole cycle of action was developed within a week in two classes. In order to put these steps into action, several texts of all modes (visual, auditory, textual) were used, such as: images of different family arrangements, a descriptive text on the terminology of different family arrangements, and finally a video in which a boy meets a gay couple for the first time ${ }^{7}$. Since this course plan refers to a foreign language teaching context, all steps aimed at developing linguistic competence (that is, improving the students' ability to position themselves in English) along with a wider educational goal aimed at inviting students to listen to the other, to look at things differently, to decenter (pre)conceptions, to expand worldviews and, mostly, to transform their own perceptions if they wish so. Such attitude towards that traditional curricular component was surely disturbing for some of those students. Nonetheless, if we acknowledge the fact that heterogeneity is one of the key elements in contemporary societies, different perspectives are to be put at stake within the classroom, especially in Teacher education programs.

Table 2.

Curricular attitude: a practical example (Duboc, 2012).

\begin{tabular}{|c|c|}
\hline \multicolumn{2}{|c|}{ EXPANDING THE NOTION OF "FAMILY" } \\
\hline stage & procedure \\
\hline Experiencing the known & $\begin{array}{l}\text { Vocabulary review aimed at the } \\
\text { theme: "family" }\end{array}$ \\
\hline Experiencing the new & $\begin{array}{l}\text { Visual literacy: interpretation on } \\
\text { different family arrangements in } \\
\text { photos including those not presented } \\
\text { by the textbook }\end{array}$ \\
\hline $\begin{array}{l}\text { Conceptualizing/ } \\
\text { Categorizing }\end{array}$ & $\begin{array}{l}\text { Explicit articulation between gender, } \\
\text { sexuality, and family }\end{array}$ \\
\hline $\begin{array}{l}\text { Finding local and } \\
\text { global connections }\end{array}$ & $\begin{array}{l}\text { Critical comparison and contrast } \\
\text { between families in the textbook, } \\
\text { the photos and real ones }\end{array}$ \\
\hline Expanding worldviews & $\begin{array}{l}\text { Understanding of the concept of family } \\
\text { in postmodern times; problematizing } \\
\text { heterogeneity and the naturalization } \\
\text { of the "non-natural" }\end{array}$ \\
\hline Transforming & $\begin{array}{l}\text { Acknowledgement of heterogeneity in } \\
\text { other social cultural practices other than } \\
\text { gender issues; acknowledgement of the } \\
\text { difficulties with coping with dissensus. }\end{array}$ \\
\hline
\end{tabular}

${ }^{6}$ The title of the textbook has not been mentioned in the paper for copyright reasons.

${ }^{7}$ Video Kid meets his first gay couple available on <http://www.youtube. com/watch?v=-4-UXtROdGo> Access September 252011.

\section{Some Conclusions}

This paper attempted to briefly highlight the main constituent aspects of post modernity in order to later discuss to what extent we might come up with a postmodern curriculum. Along with several scholars, I interpret such task as a conundrum as the very notion of curriculum has been built on modern ideas such as linearity, stability, and universality.

As discussed in the first section of this paper, the modern curriculum had long been based on concepts such as acquisition, representation, and verification of stable and universal contents. However, social transformations in late $20^{\text {th }}$ century have altered this way of knowing by the emergence of situated and heterogeneous social practices, giving room to a new look on learning, knowledge, and reality based on fresh ideas such as response, perspective, and interpretation. Post modernity, so to speak, has altered the epistemological basis inasmuch as it acknowledges that meanings are socially and culturally constructed. From that standpoint, schools would start to take into account the multiple meanings and interpretations brought by students in their various literacy practices. In view of that, what should be taught at schools in contemporary societies? Which contents are supposed to be addressed? How would they be addressed in a way that would go beyond linearity, stability, and universality?

The answer for such questions seeks support among postmodern scholars who have been discussing curricular issues for some time. As presented in the second section, when we try to come up with a postmodern curriculum, concepts such as perspective, interpretation, and response seem to be common ground among these scholars who, in a broad sense, don't provide us with clear-cut contents, abilities, and strategies to be taught in such "postmodern curriculum", but signal some new posture or attitude towards our way of teaching, inviting us to redesign our curricula in accordance to local specificities and global demands.

In view of that, I share in the third section of this paper my very own, localized curricular design which is founded by what I have been calling a curricular attitude. Conceptually speaking, postmodern principles are taken as its cornerstones. As for methodological issues, instead of thinking of a "method", I favour the notion of attitude which is then based on critique and agency.

I believe a critical perspective in education which would enable learners to actively engage in the various social practices is paramount in today's societies. When attempting to "interrupt" the circulating narrative within the classroom through a critical literacy approach, the notion of curricular attitude seeks to expand learners' worldviews. As for the agency, such notion relies on the transformative role of teachers (Kumaravadivelu, ibid.; Morgan, ibid.) who, in the very small spaces within their teaching contexts - the cracks so to speak (Duboc, 2012)would start putting into action new ways of knowing, being, and acting. Such new ways would then be founded on a new epistemological basis - a postmodern one-which embraces different perspectives, multiple interpretations, and critical responses.

In out-of-school literacy practices, many students find themselves in constant tension whenever they come up with different responses, perspectives, and interpretations; it might be interesting to take these very same elements as pre-condition to a new way of learning at schools, a way that would invite stu- 
dents to critically reflect on who they are and what makes them think the way they do in relation to who the other is and, likewise, what makes the other thinks the way he/she does. Such critical exercise might not be self-evident in textbooks, course plans or lesson plans, but might well emerge from the spaces within the curriculum.

As stated by Kumaravadivelu in the very beginning of this paper, post modernity might bring anxiety. Questionings of practical nature have been recently rising such as: What is to be taught at schools in order to respond to new demands? Which contents, procedures, resources, and purposes are appropriate in today's curricula? What is the role of teachers towards education and society? In order to answer these questions, a new logic is needed-a logic of situatedness and heterogeneity-as it is no longer possible for us to come up with one single answer that would suit all educational contexts. By presenting my local framework in the fourth section of this paper, I simply intended to illustrate one possible attitude towards the curriculum for other contexts, target groups, disciplines and the like would surely require a different curricular attitude.

When discussing the need for certain epistemic breaks in the realm of English teaching as an international language, $\mathrm{Ku}-$ maravadivelu (2012) highlights the importance of teachers in the process of breaking center-based knowledge systems. Similarly, corroborating the relevance of teaching with attitude as presented so far, Kalantzis and Cope (2008: p. 33) see teachers as change-makers, whose quoted lines conclude this paper:

Educators need to be keen observers of change. This is the only way we can keep our teaching, and our schools up to date and relevant. But, more than this, we must be agenda-setters and change-makers. We have the power to transform our classrooms and our schools.

\section{REFERENCES}

Bauman, Z. (2001). Modernidade líquida. Rio de Janeiro: Jorge Zahar Editor

Biesta, G. (2006). Beyond learning: Democratic education for a human future. London: Paradigm Publishers.

Bourdieu, P. (1996). Razões práticas: Sobre a teoria da ação. Campinas: Papirus.

Britzman, D. (1991). Practice makes practice: A critical study of learning to teach. United States: State University.

Brown, D. (1994). Teaching by principles: An interactive approach to language pedagogy. New Jersey: Prentice Hall Regents.

Burke, A. (2009). Ch.3: Checkmarks on the screen: Questions of assessment and new literacies in the digital age. In A. Burke, \& R. Hammett (Eds.), Assessing new literacies: Perspectives from the classroom (pp. 35-54). New York: Peter Lang Publishing Inc.

Comber, B. (2001). Ch. 17: Critical literacies and local action: Teacher knowledge and a "new" research agenda. In B. Comber, \& A. Simpson (Eds.), Negotiating critical literacies in classrooms (pp. 272-282). New Jersey: Lawrence Erlbaum Associates Publishers.

Comte, A. (1978). Curso de filosofia positiva; Discurso sobre o espírito positivo; Discurso preliminar sobre o conjunto do positivismo; Catecismo positivista. São Paulo: Abril Cultural.

Cordeiro, J. F. P. (2002). Falas do novo, figuras da tradição: o novo e o tradicional na educação brasileira (anos 70 e 80). São Paulo: Ed. Unesp.

Doll Jr., W. E. (1997). Currículo: Uma perspectiva pós-moderna. Porto Alegre: Artmed.

Duboc, A. P. M. (2012). Atitude curricular: Letramentos críticos nas brechas da formação de professores de inglês. Ph.D. Thesis, São Paulo: Universidade de São Paulo.

Foucault, M. (2009). A ordem do discurso (19th ed.). São Paulo: Loyola.
Foucault, M. (1984). What is Enlightenment? In P. Rabinow (Ed.), The Foucault reader (pp. 32-50). New York: Pantheon Books. http://foucault.info/documents/whatIsEnlightenment/foucault.whatIs Enlightenment.en.html

Giddens, A. (2002). Modernidade e identidade. Rio de Janeiro: Jorge Zahar Editor.

Giroux, H. A. (1993). O pós-modernismo e o discurso da crítica educacional. In T. T. Silva (Ed.), Teoria educacional crítica em tempos pós-modernos. Porto Alegre: Artes Médicas.

Graves, K. (1996). Teachers as course developers. Cambridge: Cambridge University Press. http://dx.doi.org/10.1017/CBO9780511551178

Green, B. (1997). Reading with an attitude; or deconstructing "critical literacies" response to Alan Luke and Peter Freebody. In S. Muspratt, A. Luke, \& A. Freebody (Eds.), Constructing critical literacies: Teaching and learning textual practice (pp. 227-242). Sydney: Allen \& Unwin.

Hall, S. (2004). A identidade cultural na pós-modernidade (9th ed.). Rio de Janeiro: DP\&A.

Kalantzis, M., \& Cope, B. (2008). New learning: Elements of a science of education. Australia: Cambridge University Press. http://dx.doi.org/10.1017/CBO9780511811951

Kumaravadivelu, B. (2006). Understanding language teaching: From method to postmethod. Mahwah, NJ: Lawrence Erlbaum.

Kumaravadivelu, B. (2012). Individual identity, cultural globalization and teaching English as an international language: The case for an epistemic break. In L. Alsagoff, W. Renandya, G. Hu, \& S. L. Mckay (Eds.), Teaching English as an international language: Principles and practices (pp. 9-27). New York: Routledge.

Kress, G. (2000). A curriculum for the future. Cambridge Journal of Education, 30, 133-145. http://dx.doi.org/10.1080/03057640050005825

Kress, G. (2008). O ensino na era da informação: Entre a instabilidade e a integração. In R. L. Garcia, \& A. F. B. Moreira (Eds.), Currículo na contemporaneidade: Incertezas e desafios (3rd ed.). São Paulo: Cortez Editora.

Lankshear, C., \& Knobel, M. (2006). New literacies: Everyday practices and classroom learning. New York: Open University Press.

Lyotard, J. F. (2004). A condição pós-moderna. São Paulo: José Olympio.

Macedo, R. S. (2007). Currículo: Campo, conceito e pesquisa. Rio de Janeiro: Vozes.

Menezes de Souza, L. M. T. (2006). Language, culture, multimodality and dialogic emergence. Language and Intercultural Communication, 6, 107-112. http://dx.doi.org/10.2167/laic230.0

Menezes de Souza, L. M. T. (2011). O professor de inglês e os letramentos no século XXI: Métodos ou ética? In C. Jordão, R. Halu, \& Martinez, J. (Eds.), Formação “desformatada” prática com professores de língua inglesa (pp. 279-304).. Campinas: Pontes.

Monte Mór, W. (2008). Critical Literacies, meaning making and new epistemological perspectives. Rev. Electrónica Matices en Lenguas Extranjeras, 2.

Monte Mór, W. (2010). Caderno de orientações didáticas para EJAInglês. São Paulo: Secretaria Municipal de Educação. http://portalsme.prefeitura.sp.gov.br/Projetos/BibliPed/Documentos/ publicacoes/orienta_ing_portal.pdf

Monte Mór, W. (2011). Critical literacies in the Brazilian university and in elementary/secondary schools: The dialectics between the global and the local. In R. F. Maciel, \& V. A. Araujo (Eds.), Formação de professores de línguas: ampliando perspectivas (pp. 307-318). Jundiaí: Paco.

Morgan, B. (2010). Fostering conceptual roles for change: Identity and agency in ESEA teacher preparation. Kritika Kultura, 15, 34-55.

Morin, E. (2005). A cabeça bem-feita: Repensar a reforma, reformar o pensamento. Rio de Janeiro: Bertrand Brasil.

Muspratt, S., Luke, A.; Freebody, P. (1997). (Eds.). Constructing Critical Literacies. Cresskill, New Jersey: Hampton Press.

Pennycook, A. (2001). Critical applied linguistics: A critical introduction. New Jersey: Lawrence Erlbaum Associates, Inc.

Richards, J. C. (1989). The context of language teaching. United King- 


\section{A. P. M. DUBOC}

dom: Cambridge University Press.

Shor, I. (1999). What is critical literacy? The Journal of Pedagogy, Pluralism and Practice, 1.

Silva, T. T. (2010). Documentos de identidade uma introdução às teorias do currículo (3rd ed.). Belo Horizonte Autêntica.

Torres, C. A. (2003). Teoria crítica e sociologia política da educação.
São Paulo: Cortez.

Wooldridge, N. (2001). Tensions and ambiguities in critical literacy. In B. Comber, \& A. Simpson (Eds.), Negotiating critical literacies in classrooms (pp. 259-270). New Jersey: Lawrence Erlbaum Associates Publishers. 